\title{
“BERKUBANG DALAM LUMPUR, BEKERJA BERSAMA ORANG MISKIN" Wajah Keterlibatan Sosial Gereja Ganjuran
}

\author{
Alis Windu Prasetyo dan Dionius Bismoko Mahamboro
}

\begin{abstract}
:
The Catholic Church in Asia has declared triple-dialogue (dialogue with the Asian cultures, with religions and with the poor) as its "way of being Church". The farmers belong to the poor in most of Asian countries, especially in Indonesia. This article tries to trace back the history of the Asian Church's concern with the farmers, which are the representation of the poor. This concern has inevitably touched socio-cultural and socio-political dimensions of christian faith, which lead the christian communities to the most concrete social problem of the local communities, and at the same time connect them with global issues like hunger and food industrialization, or ecological crisis and sustainable farming.
\end{abstract}

\section{Kata-Kata Kunci:}

Hari Pangan Sedunia (HPS), Ajaran Sosial Gereja (ASG), Deklarasi Ganjuran, FABC, ekologi, petani, Gereja Asia.

\section{PENDAHULUAN}

Sejak dicanangkannya Hari Pangan Sedunia (HPS) oleh Food and Agriculture Organization, (FAO, Organisasi Pangan dan Pertanian PBB) pada tahun 1979 untuk diperingati setiap tanggal 16 Oktober, Gereja Katolik ikut memperingatinya. Untuk membangkitkan kesadaran umat Katolik akan persoalan kekurangan pangan, paus dan uskup-uskup menuliskan pesan khusus atau surat gembala dalam rangka HPS setiap tahunnya. Mgr. Ignatius Suharyo, Uskup Agung Jakarta, misalnya mengangkat isu kemiskinan: 24 juta orang di seluruh Indonesia mengalami kelaparan. ${ }^{1}$ Melalui surat gembala dalam rangka HPS, Mgr. Suharyo juga menghubungkan persoalan pangan dengan persoalan ketidakpedulian manusia terhadap lingkungan.

"Ketidakpedulian kita terhadap alam menyebabkan tanah makin rusak dan tidak subur, air makin kotor dan tercemar, udara makin panas dan mengandung racun. Itu semua ikut mempengaruhi secara negatif produksi pangan. Karena itu, gerakan peduli pangan tidak bisa dipisahkan dari gerakan peduli lingkungan hidup.” (Nr. 7).

Sementara itu, Paus Fransiskus mengangkat pentingnya pendidikan solidaritas untuk menyumbang pemecahan persoalan kelaparan. ${ }^{2}$ Ketika banyak orang kelaparan, di belahan dunia yang lain banyak makanan terbuang percuma. "It is a sad sign of the "globalization of indifference" which slowly leads us to grow "accustomed" to the suffering of others, as though it were normal." tulis Paus Fransiskus. Ketidakpedulian (indifference) menjadi kata kunci baik dalam surat gembala Mgr. Suharyo maupun pesan Paus Fransiskus untuk mengerti tentang kemiskinan.

Di berbagai tempat di Indonesia, peringatan HPS diselenggarakan oleh berbagai organisasi kemasyarakatan seperti paguyuban petani yang tergabung dalam Keluarga Besar Paguyuban TaniNelayan Hari Pangan Sedunia (KBPTN HPS). Sekretariat Pelayanan Tani dan Nelayan (SPTN) menjadi motor kegiatan ini. Selanjutnya, gerakan 
para petani ini seringkali dikenal sebagai gerakan pertanian organik atau tani lestari. Kendati melibatkan kelompok-kelompok petani umum dan lembaga-lembaga swadaya masyarakat, gerakan ini ternyata dimulai dari lingkup Gereja. Sejak akhir tahun 90-an, Paroki Ganjuran di Keuskupan Agung Semarang (KAS) mengadakan peringatan HPS. Secara kebetulan, peringatan HPS pada tahun 1990 melahirkan Deklarasi Ganjuran yang menandai berdirinya Paguyuban Petani dan Nelayan HPS. Dari sejarah perkembangannya, gerakan petani ini tak lepas dari arus keprihatinan sosial Gereja di Asia yang ingin menjadi "Gereja Kaum Miskin”. Mengapa demikian? Karena gerakan tani lestari ini merupakan salah satu bentuk keterlibatan sosial Gereja di konteks Asia. Perwujudan ini meliputi gerak kelembagaan para uskup Asia dalam FABC dan gerak Gereja lokal sebagai perwujudan yang lebih konkrit. Dengan kata lain, gerakan ini terjadi di tingkat akar rumput dan hirarki. ${ }^{3}$

\section{FRAGMEN KEMISKINAN: PETANI DI INDONESIA}

\subsection{Masalah Pertanian, Masalah Lingkun- gan Hidup}

Rm. Gregorius Utomo adalah sosok yang tidak bisa dilepaskan dari Deklarasi Ganjuran. Suatu ketika dalam peringatan HPS di Balai Desa Banjarasri, Kalibawang, Kulon Progo, ia berkata, "Barangsiapa menguasai benih, menguasai kehidupan. Oleh karena itu, kembalikan kedaulatan benih kaum tani demi kedaulatan kaum tani dan negeri ini!" 4 Apa yang dikatakan pastor yang kini berusia 86 tahun itu adalah keprihatinan yang lama telah ia gulati dan geluti. Tulisan-tulisannya, entah makalah seminar, artikel untuk buku atau jurnal, mempunyai benang merah yang sangat kuat, yaitu keutuhan ciptaan, hubungan manusia dan semesta. Secara nyata, selama ini ia memberi perhatian pada bidang pertanian dan ambil bagian dalam gerakan kaum tani. Mengapa ia tertarik pada pertanian? Tentu saja karena ia melihat ada masalah dalam pertanian di Indonesia. Negeri agraris ini belum mengizinkan para petaninya menikmati kemakmuran. Mereka terpinggirkan, salah satunya oleh industrialisasi pertanian. Pengelolaan bumi dengan cara seperti itu tentu juga menimbulkan permasalahan lingkungan hidup. Indonesia, seperti negara-negara dunia ketiga lain, menghadapi krisis ekologi yang erat kaitannya dengan pemiskinan. $^{5}$

Gerakan Rm. Utomo sering dikaitkan dengan pertanian organik dan Deklarasi Ganjuran walau ia bukan pencetusnya, apalagi perancangnya. Peristiwa itu 'spontan' dan sering disebut oleh Rm. Utomo sebagai 'momentum khairos'. Dalam wawancara, ia mengatakan bahwa seluruh gerakan pertanian lestari dikerjakan bersama dengan rekan-rekan yang sadar akan kedaulatan manusia dan semesta yang harus dibela dan diperjuangkan. Mengapa dibela? Karena kemajuan teknologi dapat memperbudak manusia untuk serakah. Manusia menjajah semesta sehingga rusaklah alam dan ciptaan lainnya. ${ }^{6}$ Itulah yang terjadi dengan pertanian di Indonesia. Deklarasi Ganjuran pun bukan sebuah peristiwa besar yang gegap gempita. Peristiwa itu cukup pantas disebut 'acara tambahan' dalam perhelatan AISA V (Asian Institute of Social Action ke-5) pada tahun 1990 yang diselenggarakan oleh Federasi Para Uskup Asia (FABC). Acara tersebut 'ditepatkan' dengan peringatan HPS tahun itu. Cerita singkatnya kurang lebih demikian: Ketika Rm. Utomo masih bertugas di LPPS KWI, datang tawaran kepada Konferensi Uskup-uskup Indonesia (KWI) untuk menjadi tuan tumah AISA ke-5, bulan April 1990. Ganjuran bersedia, asal pelaksanaan AISA ditangguhkan sampai bulan Oktober, bertepatan dengan rangkaian pelaksanaan Hari Pangan Sedunia. Acara ini diselenggarakan tanggal 9-16 Oktober 1990. Pemilihan tempat ini, terkait dengan kondisi paroki Ganjuran pada saat itu.

\subsection{Geliat Paroki Ganjuran}

Saat itu Rm. Utomo baru dua tahun bertugas di Ganjuran. Selain mendapat tugas sebagai pastor paroki, ia menjabat sebagai konsultor Keuskupan Agung Semarang, di saat keuskupan sedang bergulat dengan arah dasarnya (Ardas) yang pertama.

Mulainya HPS di Paroki Ganjuran tahun 1988, bertepatan dengan event 64 tahun (jw. tumbuk ageng) Paroki Ganjuran. Salah satu karya yang dibuat Rm. Utomo adalah menggali spiritualitas paroki Ganjuran. Beliau mencari informasi sampai ke Belanda, menyusuri majalah misi Yesuit Claverbond, demi memahami sejarah paroki. Dalam sejarah didapati bahwa perkembangan umat Ganjuran tak lepas dari peran Dr. Jos dan Ir. Jules Schmutzer. Merekalah orang Katolik saat itu yang mencoba melaksanakan Ajaran Sosial Gereja mengenai asas-asas solidaritas. Di lingkup pabrik gulanya, ia semata-mata tidak cari keuntungan. Pabriknya akan maju kalau karyawannya sejahtera. Pada tahun 1927, Schmutzer mendirikan candi Tyas Dalem. Kiranya devosi terhadap Hati Kudus Yesus sedang berkembang di Eropa. Schmutzer mendirikan candi sebagai ungkapan terima kasih karena perlindungan Tyas Dalem terhadap 
usahanya. Selain itu, mereka juga mendirikan banyak sekolah dan rumah sakit (Ganjuran dan Onder de Bogen alias RS Panti Rapih Yogyakarta). ${ }^{\text {' }}$

Berangkat dari sejarah itu, Rm. Utomo mengembangkan spiritualitas paroki: Gereja mesti berwajah sosial. Untuk itu ia mendorong umat berteologi (membaca Kitab Suci), membangun asas kemuridan (semuanya adalah murid, semua perlu belajar, tak ada yang lebih pandai), asas musyawarah, solidaritas, subsidiaritas, dan iman yang memasyarakat. Ardas saat itu (periode 1984-1990) mempunyai salah satu kata kunci yakni iman yang memasyarakat. Peringatan HPS tiap bulan Oktober adalah usaha umat Ganjuran untuk memasyarakatkan imannya. Isi acaranya macam-macam, seperti pentas seni dan sarasehan, baik internal dan eksternal.

\subsection{Deklarasi Ganjuran}

'Momentum khairos' yang sering disebut Rm. Utomo adalah bersedianya Ganjuran jadi tuan rumah AISA atau pelatihan keterlibatan sosial bagi awam. Di sinilah bergulir Deklarasi Ganjuran. Seruan ini berisi pernyataan sikap para petani yang mengikuti rangkaian acara HPS di Ganjuran mengenai situasi pertanian dan nasib para petani:

Delapan puluh persen lebih penduduk Indonesia adalah petani. Namun sampai saat ini petani tak banyak yang mengalami peningkatan kesejahteraan. Berdasarkan pertimbangan itu, para petani memberi himbauan kepada pemerintah untuk lebih mendukung prakarsa-prakarsa kelompok tani. Selain itu, dihimbau juga kepada Gereja untuk semakin lebih menampakkan keberpihakannya kepada rakyat miskin, dalam hal ini para petani. Deklarasi juga menandai jaringan kerjasama di antara para petani di tanah air.

Petikan pesan deklarasi ini jelas: peningkatan kesejahteraan petani yang termasuk kelompok orang miskin. Namun ironisnya, Indonesia adalah negeri agraris. Seruan Rm. Utomo mengenai kedaulatan benih tadi menyangkut kemandirian petani yang menjadi amanat Deklarasi Ganjuran. Hingga tahun 1990-an -lebih tepatnya selama masa rezim Orde Baru- petani 'dibuat' tidak mandiri. Mengapa demikian?

Salah satu program pemerintah Orde Baru adalah pertumbuhan ekonomi. Di balik ideologi ini terdapat cara berpikir pragmatis. Di bidang pertanian, ideologi ini terjelma dalam wujud program revolusi hijau sekitar tahun 60-an hingga 80-an, yaitu ekstensifikasi dan intensifikasi pertanian yang digencarkan untuk mendongkrak produksi pertanian. ${ }^{8}$ Istilah 'revolusi hijau' lazim digunakan untuk menunjuk modernisasi pertanian, khususnya tanaman pangan, yang mengandalkan asupan kimiawi dan biologi ke dalam kultur bercocok tanam tanaman pangan pokok. Dengan demikian, paradigma pertanian melulu diarahkan pada segi ekonomi. Awalnya, penanganan sektor pertanian oleh pemerintah bertujuan meningkatkan produksi pertanian. Dengan program intensifikasi dan ekstensifikasi, Indonesia pernah dipandang berhasil menyediakan bahan pangan untuk keperluan dalam negeri (swasembada beras). Untuk itu, presiden Indonesia kala itu, Soeharto, mendapat penghargaan dari lembaga PBB untuk urusan pangan dan pertanian, FAO, pada tahun 1989 di Roma, Italia. Namun ternyata ketika diluncurkan program revolusi hijau, Indonesia menceburkan diri dalam arus industrialisasi dan kapitalisasi. Rm. Utomo sering menyebut 'perang benih' dan mengatakan bahwa siapa yang menguasai benih, ia menguasai kehidupan. ${ }^{9}$ Program-program pertanian dari pemerintah mengharuskan petani memakai pupuk, benih, dan sistem pengairan yang sudah ditentukan pemerintah. Ini menyebabkan para petani tergantung pada pemasok benih dan pupuk yang mestinya bisa mereka usahakan sendiri. Semakin lama, benih yang mereka kenal hanyalah varietas IR, hasil eksperimen padi di International Rice Research Institute (IRRI), Los Banos, Filipina. Maka tidak berlebihan jika dikatakan bahwa petani Indonesia selama ini menjadi 'tahanan politik' bank benih itu. ${ }^{10}$ Ini belum seberapa. Yang lebih parah adalah, para petani 'dijadikan orang bodoh'. Mungkin banyak orang sekarang sudah lupa pada program 'Klompencapir', kelompok pendengar pembaca pemirsa, yang disiarkan oleh TVRI. Jika petani hanya jadi pendengar, pembaca dan penonton, kapan mereka punya kesempatan berbicara?

Revolusi hijau yang agen dan kegiatannya adalah BIMAS, INMAS, SUPRA INSUS, dsb. ini sebenarnya mengusung agenda neokolonialisme baru atau istilah sekarang lebih dikenal dengan neoliberalisme baru yang bernama GATT (General Agreement on Tariffs and Trade) yang pelakunya adalah negara-negara maju (dunia pertama). ${ }^{11}$ Mereka semua adalah negara industri yang mencoba menguasai dunia dengan segala kebijakannya. Sekarang, penguasa perdagangan bahkan tidak hanya negara tetapi para kapitalis dengan perusahaan-perusahaan multinasional (MNC). Bahkan MNC ini jauh lebih kaya dibandingkan negara maju sekalipun. Segala 
kritikan terhadap GATT/WTO, Bank Dunia, IMF yang dengan berbagai resepnya bagi negaranegara berkembang telah banyak terjadi akhirakhir ini. Gerakan-gerakan semakin meluas karena masyarakat semakin mengerti bahwa jurang kaya dan miskin semakin lebar, juga perusakan bumi karena eksploitasi alam seperti industrialisasi pertanian, harus segera dihentikan. ${ }^{12}$ Deklarasi Ganjuran mengajak petani untuk kembali ke model pertanian yang 'tidak industrialis' dan ramah lingkungan. Pertanian organik menjanjikan kemandirian petani. Pada tahun 1990-an, model bercocok tanam ini tidak populer. Salah satu sebabnya, petani yang berani tidak ikut program pemerintah bisa berurusan dengan aparat.

Di balik seluruh gerakan lokal yang berorientasi global ini terdapat persoalan otonomi dan kemandirian masyarakat desa yang sebenarnya dimatikan dengan adanya UU No. 5 Th. 1974 dan UU No. 5 Th. 1979. Keduanya mengatur mengenai penyeragaman bentuk pemerintahan desa. Namun UU ini tak diberlakukan lagi dengan berlakunya UU No. 22 Th. 1999. Walau demikian, sekarang pengaruh UU tersebut masih tetap berjalan, masyarakat sudah terlanjur dimatikan kemandiriannya. ${ }^{13}$ Masyarakat desa mestinya proaktif dalam mewujudkan otonomi desa termasuk pelaksanaan eko-politik (politik pelestarian lingkungan hidup). Masyarakat desa/tani harus proaktif membela dan menegakkan hak-hak desa termasuk pelaksanaan eko-politik dalam cakupan otonomi. Otonomi desa adalah hak desa, bukan pemberian pemerintah Hindia Belanda atau RI. ${ }^{14}$ Kemandirian benih termasuk kemandirian desa juga.

\section{4. 'Dari Hulu, Bukan Hilir'}

Berkaitan dengan soal pangan ini, menurut Rm. Utomo, Gereja perlu menyelesaikan bukan seperti kebanyakan penyelesaian saat ini tetapi diharapkan mampu lebih melihat akar permasalahannya. Ia menyebutkan sebagai penyelesaian ke hulu daripada hilir. Ia menyebut hulu dalam kaitan dengan ketahanan pangan ini adalah persoalan keseharian. Kalau keseharian sudah kurang diperhatikan, pengaruhnya juga akan sangat besar dalam sektor kehidupan yang lain. Penyelesaian hulu bermaksud menyelesaikan masalah tidak hanya tambal sulam. Kalau ada kerusakan tanah, justru kita perlu mengembalikan kondisi tanah secara alamiah, bukan dengan menambah kerusakan dengan pestisida atau bahan kimia lain. Ini akan berdampak pada pola pertanian yang organik, alamiah, dan bukan kimiawi dengan segala macam pupuk kimia- pabrik, benih tanaman yang sudah direkayasa genetika, dan sebagainya. Memang hasil dan kemasan yang sudah direkayasa jauh lebih menarik. Tetapi bahaya di dalamnya sangatlah jahat. Oleh karena itu, kerusakan tanah menjadi 'PR' kita bersama untuk mengembalikan lagi unsur-unsurnya yang alami sehingga tanah kembali bisa ditanami. Inilah salah satu 'hulu' dari ketahanan pangan.

Komunitas petani organik tampaknya mau menunjukkan bahwa pola kehidupan organik ini dapat mempengaruhi mentalitas manusia yang menjalankannya. Penyelesaian hulu masalah menuntut manusia yang sadar akan alam, lingkungan, ekosistem yang berarti sadar akan semesta, kosmos ini. Ekologi dan kosmologi menjadi perlu supaya manusia yang menjadi bagiannya tidak salah arah dan olah. Visi paguyuban yang tertuang dalam Deklarasi Ganjuran berakar pada spiritualitas belas kasih dan berkat. Belas kasih dan berkat berarti siap mengamalkan belas kasih Tuhan, siap menjadi berkat Tuhan bagi bumi, seluruh sesama, dan sesama ciptaan Tuhan (Luk 6:36; Kej 2:2-3). Maka, gerakan pertanian lestari juga merupakan gerakan moral karena krisis ekosistem adalah kirisis moral. Kemudian, tanggung jawab atas keseimbangan tatanan ciptaan adalah unsur esensial iman. Ini bukan berarti menolak kemajuan teknologi. Yang ditolak adalah teknologi yang tak bermoral, yaitu teknologi yang merusak. Belas kasih merupakan 'gaya hidup', demikian ungkap Rm. Utomo. Dari Perjanjian Lama (Yes 61:1-2) yang kemudian dikutip Lukas, dibuktikan bahwa belas kasih selalu aktual dalam kehidupan ini. Yesus selalu mengamalkan apa yang didapat dari belas kasih Bapa dalam kehidupannya. "Hendaklah kamu berbelas kasih seperti Bapamu di surga itu berbelas kasih” (Luk 6:36). Belas kasih pun bersifat kosmik. Artinya, artinya "belas kasih Allah mencakup segala yang dijadikann-Nya" (Mzm 145:9). Di sini, "belas kasih" - "menciptakan"/"memberkati” - "berkat" (ciptaan Allah) merupakan satu kesatuan. ${ }^{15}$

Lantas, bagaimana konkretisasi paguyuban/komunitas yang ingin dibentuk? Tani organik bukan melulu hanya berorientasi pada hasil pertanian atau kaum tani saja. Tani organik atau tani lestari sebenarnya mau diarahkan pada tujuan lebih luas yaitu menciptakan komunitas dunia yang lestari juga. Disebut oleh Rm. Utomo, komunitas yang dibangun adalah self-reliance, community-based, and community-supported. Artinya, komunitas itu mandiri dan berswadaya. ${ }^{16}$ 
Jadi, apakah paguyuban tani lestari merupakan salah satu bentuk 'komunitas-komunitas pembebasan' dalam konteks Asia? Suatu wajah keterlibatan sosial Gereja?

\section{KETERLIBATAN SOSIAL GEREJA ASIA: GERAK BERSAMA FABC}

Jauh-jauh hari sebelum gagasan untuk membentuk sebuah kerjasama antar para uskup di kawasan Asia, kesadaran akan perlunya keterlibatan sosial Gereja di tengah masyarakat sudah mengemuka di antara para imam dari beberapa negara di benua Asia. Semangat misi Gereja di tengah masyarakat dunia yang serba berubah ini pada tahun 1965 terkristalisasi dalam dokumen Konsili Vatikan II, Lumen Gentium. Rupanya 'roh' gerakan ini sampai pula di Asia. Pada bulan Agustus 1965 di Hongkong, digelarlah Priests' Institute for Social Action (PISA). Seminar-pelatihan ini bertujuan menggali dimensi-dimensi baru kerasulan Gereja dalam keterlibatan sosial. Perhelatan tersebut diikuti oleh 150-an imam, juga awam dan aktivis sosial. Kesadaran mengenai dimensi-dimensi sosial dalam kerasulan Gereja ini terus bergulir dan menjadi 'roh' dari 'tripledialogue', khususnya dialog dengan orang miskin.

\subsection{Office For Human Development ${ }^{17}$}

Setelah PISA, terasalah kebutuhan akan adanya koordinasi aksi sosial Gereja di Asia. Pada bulan Juni 1969 sekitar 40 orang yang terdiri dari uskup, imam, dan awam berkumpul di Jesuit House, Baguio, Filipina, untuk bertukar pengalaman mengenai keterlibatan sosial mereka di tempat masing-masing. Mereka juga berusaha mencari cara supaya bisa bekerjasama. Dalam pertemuan itu, beberapa uskup berbincang-bincang secara informal. Menurut mereka, tentunya akan sangat membantu jika ada suatu pusat koordinasi kegiatan sosial yang dikelola secara full-time. Nantinya ini akan terwujud menjadi Office for Human Development (OHD) atau Kantor Pengembangan Manusia. Untuk pertama kalinya, pusat koordinasi ini diketuai oleh Uskup Julio Xavier Labayen dari Filipina yang dibantu oleh Rm. Horacia De La Costa sebagai sekretarisnya.

Nama 'Office for Human Development' tentunya memuat keprihatinan tertentu yang menyangkut upaya Gereja Asia untuk terlibat dalam masalah-masalah sosial. Keprihatinan ini mendapatkan dukungan angin segar buah-buah pemikiran Paus Paulus VI dalam ensiklik Populorum Progressio (1967). Keterlibatan sosial tak lain bertujuan untuk meningkatkan kualitas hidup manusia. Menyitir kata-kata Paus, perkembangan manusia yang sejati ialah peralihan dari kondisi yang kurang manusiawi ke kondisi yang sungguh-sungguh manusiawi (PP 20). Dalam suatu kunjungan ad limina, Mgr. Labayen menceritakan kiprah OHD; visi, harapan, dan inspirasi yang digali dari PP. Paus amat mendukung gagasan itu.

Bulan November 1970 dapat dikatakan sebagai tonggak penting bagi Gereja Asia. Pada bulan ini, Paus Paulus VI berkunjung ke Filipina. Lebih dari ratusan uskup dari segala penjuru benua Asia menjumpai paus. Perjumpaan para uskup ini melahirkan gagasan untuk membentuk federasi konferensi para waligereja sebagai forum saling bertukar pengalaman, untuk membangun jejaring yang lebih baik antaruskup Asia serta untuk saling mengenal dengan lebih baik. Terangkatlah pula visi Gereja Asia, lebih daripada sekedar federasi dari konferensi waligereja negara-negara di Asia. Visi ini sampai sekarang umum diungkap dengan rumusan 'A New Way of Being Church'. Thomas C. Fox menyebutnya: Asian Catholicism. Cara (way) menggambarkan respon terhadap kenyataan benua Asia yang dihuni oleh dua pertiga populasi dunia, yang kebanyakan miskin dan bukan kristiani.

Di bulan yang sama, tanggal 23, Kardinal Darmojuwono dari Indonesia, Uskup Hsu dari Hongkong, Uskup Labayen dari Filipina, dan Rm. De La Costa bertemu dengan perwakilan Misereor, suatu lembaga bantuan sosial (Hilfswerke) dari Gereja Katolik Jerman, untuk membahas kemungkinan-kemungkinan diintegrasikannya OHD ke dalam federasi konferensi para uskup Asia (Di Hongkong, Maret 1971, diadakan Asian Bishops' Meeting yang lalu menjadi cikal-bakal FABC; FABC dinyatakan secara resmi berdiri pada November 1972). Setahun berikutnya, Desember 1971, OHD secara resmi berada di bawah koordinasi FABC dengan perubahan arah yang cukup penting: melayani seluruh Gereja Asia (sebelumnya lebih terkonsentrasi di sekitar Asia Timur dan Tenggara).

Visi dan misi OHD terarah pada perwujudan dan konkritisasi makna 'A New Way of Being Church'. Pemahaman misi yang dikembangkan di Asia menjangkau bidang-bidang berikut:

- Dialog menyeluruh dalam konteks situasi multireligius, keragaman budaya, dan fenomena jurang antara yang kaya dan miskin;

- Usaha meningkatkan kesejahteraan dan tindakan amalkasih, promosi pembangu- 
nan manusia yang integral dan advokasi untuk perdamaian dan keadilan;

- Isu-isu gender, kerjasama antaragama, dan pemeliharaan keutuhan ciptaan;

- Perhatian khusus terhadap komunitaskomunitas kaum muda, perempuan, anakanak, keluarga, penduduk asli dan orangorang imigran.

\subsection{Bishops' Institute for Social Action (BI- SA)}

Dorongan untuk masuk ke dalam keterlibatan sosial di tengah masyarakat Asia yang melahirkan OHD juga terinspirasi oleh ensiklik Paus Paulus VI 'Populorum Progressio': "Pembangunan manusia adalah suatu proses mengubah kondisi yang kurang manusiawi menjadi lebih manusiawi.” Setelah bentuk kelembagaan OHD mulai jelas, dimulailah serangkaian seminar/kursus bagi para uskup untuk mendalami arti perkembangan manusia (human development). Kegiatan ini disebut Bishops' Institute for Social Action (BISA). Putaran pertama digelar tanggal 1-15 Maret 1974, di Novaliches, Manila, Filipina. Selanjutnya, BISA II digelar pada 7-9 April 1975 di Tokyo, Jepang, BISA III pada 2-16 November 1975, di Kuala Lumpur, Malaysia, BISA IV pada 28 Februari-8 Maret 1978, di Korea, BISA V pada 27 Mei-1 Juni 1979 di Baguio, Filipina, BISA VI pada Februari 1983 di Srilanka, dan BISA VII pada Januari 1986 di Thailand. Berikut sekilas refleksi final setiap pertemuan BISA:

- BISA I-III: merumuskan dimensi sosial Injil dalam konteks Asia. Komitmen kepada orang miskin bukan berarti bekerja untuk orang miskin, maupun bersama orang miskin. Maka langkah pertama adalah hidup dan bersentuhan dengan mereka (BISA II April 1975).

- $\quad$ BISA IV-VI: menekankan tanggungjawab kolegialitas para uskup terhadap 'human development'. Para uskup bertindak dalam kolegialitas atau sebagai saudara. Dalam BISA IV-V ditekankan metode eksposur di tengah orang miskin untuk melihat penyebab kemiskinan mereka. Tantangan bagi kemajuan dan perkembangan manusia adalah militerisasi, kebangkitan agama-agama tradisional Asia dan ketergantungan Asia terhadap ekonomi global.

- BISA VII: di sini dibicarakan dan dikembangkan metode spiral pastoral.
Tema yang diangkat ialah “Asia's ReligioCultural Heritage and Human Development'. Para uskup yang hadir sebagian besar berasal dari benua Asia. Tampak hadir pula beberapa uskup dari benua lain.

Secara khusus, BISA VII perlu disoroti karena muatan pentingnya bagi kelanjutan dan perkembangan keterlibatan sosial Gereja Asia. Tema di atas diangkat sebagai kesepakatan bersama para uskup untuk merefleksikan warisan religi-budaya dan pengembangan manusia. Para uskup betulbetul menyadari bahwa budaya dan agama saling berkaitan erat. Maka kemiskinan dalam konteks Asia tidak sekedar beraspek ekonomis saja, atau budaya saja, atau religius saja. Oleh karena itu, di dalam kenyataan akan adanya warisan religibudaya yang kaya dan beragam ini, para uskup perlu untuk menemukan daya-daya kreatif dari Roh Allah yang membebaskan seperti dalam perjuangan orang-orang miskin untuk melepaskan dirinya dari kemiskinan dan penindasan serta berjuang untuk membangun communion yang sejati antar warga dan antarbangsa. Dalam perspektif ini, uskup berperan sebagai pemimpin spiritual dari keuskupannya masing-masing. Ia bukan pertama-tama menjadi koordinator, tetapi animator.

Para animator perlu mengenali dan memahami spiritualitas di dalam nilai-nilai kultural-religius yang positif dari orang-orang miskin. Untuk itu mereka perlu memiliki pengalaman yang mendalam akan Allah dalam doa dan juga pengalaman akan Allah yang sama dalam diri orang-orang miskin. Para animator perlu bersentuhan ('immersion in poverty', bukan hanya 'exposure to poverty') dengan orang miskin supaya berbagi dan bertumbuh bersama mereka, serta 'dipertobatkan' oleh mereka (Refleksi Akhir BISA VII no. 4: 'being evangelized by the poor'). Pengalaman bersama orang miskin nantinya diolah dengan metode spiral pastoral (exposure-immersion, social analysis, theological reflection/contemplation, pastoral planning).

\subsection{Asian Institute for Social Action (AISA)}

Rupanya, metode ini belum teruji di tingkat gereja lokal. Gagasan untuk menyelenggarakan Asian Institute for Social Action (AISA) lahir dari kebutuhan untuk menguji metode dinamika pastoral. Tidak hanya itu, penyelenggaraan AISA sebetulnya juga didorong oleh kebutuhan untuk memperdalam komitmen Gereja Asia untuk menjadi ‘Gereja Orang Miskin' dengan perhatian khusus terhadap para pekerja/buruh sebagai persiapan peringatan 100 tahun Rerum Novarum (1891). 
Setelah usia Rerum Novarum yang ke-100 tahun, bagaimana para uskup menerapkan Ajaran Sosial Gereja di tempat masing-masing? Maka sebagai hasil dari BISA VII, serangkaian AISA yang hendak digelar bertujuan untuk menyediakan bagi tiap konferensi waligereja anggota FABC kesempatan dan metode yang akan menjadi sumbangan dalam perayaan ultah satu abad ensiklik Paus Leo XIII itu.

Untuk yang pertama kalinya, AISA diadakan di Antipolo, Filipina, 28 Agustus - 5 September 1987. Temanya "Becoming the Church of the Poor with Special to Industrial Workers”. Secara lebih spesifik, tujuan AISA ialah untuk merencanakan langkah yang konkrit di tingkat keuskupan, nasional, dan Asia; untuk mewujudkan Gereja Asia sebagai Gereja Kaum Miskin; untuk menghubungkan aspek kultural-religius dari kehidupan para pekerja dengan aspek sosio-ekonomis-politis, khususnya melalui doa dan liturgi. AISA merupakan fase lebih lanjut setelah serangkaian BISA. Perbedaannya ialah bahwa AISA lebih terfokus pada uskup dan program kerjanya dalam kebutuhan keuskupannya. Program AISA masih dikoordinasi OHD, walau penyelenggaraan sepenuhnya dipersiapkan oleh Gereja lokal.

Seperti yang telah dipaparkan di atas, Indonesia pernah menjadi tuan rumah penyelenggaraan AISA, yakni putaran ke-5 yang berlangsung tanggal 9-16 Oktober 1990 dan bertempat di Ganjuran, Yogyakarta. Dari perhelatan inilah muncul 'Deklarasi Ganjuran' yang melahirkan paguyuban tani dan nelayan Hari Pangan Sedunia (HPS). Dari latar belakang pertemuan AISA V dan peringatan HPS tahun 1990 itu yang bertema "Gereja Asia, Gereja Kaum Tani”, kita dapat melihat upaya Gereja lokal untuk mewujudkan gagasan keterlibatan sosial yang diolah dan digeluti di tingkat hirarki/keuskupan.

\section{TAMBATAN KETERLIBATAN SOSIAL DI ASIA}

Setelah melihat wajah keterlibatan sosial gereja 'lokal' (Ganjuran, KAS) yang disambungkan dengan impian-impian para uskup Asia untuk mewujudkan 'new way of being church', kita beralih pada beberapa gagasan dasar yang menjadi benang merah. Sebagai titik tolak refleksi atas keterlibatan sosial Gereja Asia, disodorkan dua tesis dari '15 Tesis Gereja Lokal $^{18}$ yang disusun oleh Komisi Penasihat Teologis FABC (Theological Advisory Commission). Dalam bagian tesis mengenai dasar biblis, khususnya pada tesis 3, dipaparkan mengenai misi Gereja yakni pewartaan Sabda.

In the Church the ministry of the Word is carried out through the apostolic teaching, the eucharistic celebration, the spirited-filled life and activity and proclamation of salvation. Hence, these elements are generative and contitutive of the local Church. But they will be productive of the local Church only as appropriated by concrete groups of men and women in response to the Word of God. The apostolic ministry is a contituent of the local Church, whose structure should be such as to foster the nature of the local Church as that community in which the Christosentric saving act of God is ever present.[tesis 3]

Identitas Gereja pada dasarnya ialah 'pewartaan Sabda' yang diwujudkan melalui pembentukan jemaat (koinonia), perayaan liturgi (liturgia), kegiatan pelayanan (diakonia), dan pewartaan (kerygma). Dengan demikian, karya penebusan Kristus diwartakan kepada semua orang. Jadi, panggilan Gereja juga untuk mewujudnyatakan pewartaan Sabda sampai kepada karya-karya pembebasan orang-orang yang terbelenggu. ${ }^{19}$ Dalam rangka mengikuti 'strategi' Yesus Kristus dalam konteks gereja Asia, pembebasan mestinya mencakup dimensi-dimensi manusia secara integral. Lebih tegas lagi, misi Gereja (lokal) diwujudkan dengan keterlibatan dalam perjuangan keadilan, hak-hak azasi manusia dan martabat manusia, dan dalam perjuangan membela orang-orang miskin.

In Asia a local Church realizes itself by entering into new relationship with neighbours of other faith and by involving itself in concern of justice, human dignity and human rights, and in the concrete fulfillment of preferential love for the poor.[tesis 7]

Ketika Gereja memasuki dan terlibat dalam pembelaan keadilan dan perjuangan meningkatkan mutu hidup manusia, ia tidak bisa lepas dari situasi sosial, budaya, dan politik. Maka Gereja tak lepas dari proses modernisasi, namun juga perlu mengkritisi proses tersebut. Modernisasi perlu disaring dengan kepedulian terhadap orang miskin dan terpinggir dalam masyarakat Asia. Petani di Asia adalah kelompok masyarakat yang tak cukup mampu mengikuti arus modernisasi pertanian. Dalam potret nasib petani di Indonesia, modernisasi dimotori oleh pemerintah yang terdorong untuk meningkatkan kemajuan ekonomi. Masalah ini jugalah yang menjadi medan perjuangan para uskup Asia. Dalam refleksi-refleksi teologis, masalah pertanian kerap muncul. Masalah krisis ling- 
kungan hidup dan keutuhan ciptaan di wilayah Asia mau tidak mau terjalin dengan masalah marginalisasi kaum tani dan penurunan kualitas hidup mereka.

Oleh karena itu, dari gerakan petani lestari di Ganjuran yang menyebar sampai ke seluruh Indonesia, dan dari dinamika gerak Gereja Asia di level para uskup, dapat disarikan unsur-unsur 'new way of being church in Asia ${ }^{20}$ dalam dimensi keterlibatan sosial ${ }^{21}$ :

- Communion of community -Gereja yang terdiri dari berbagai macam orang, baik religius maupun non-religius dipanggil bersama-sama oleh Sabda Allah untuk membangun komunitas. Semua anggota komunitas itu berdoa dan berbagi bersama akan Kabar Gembira Yesus, hidup bersama dalam keseharian, mendukung satusama lain dan bekerja bersama dalam kesatuan hati dan budi.

- Gereja yang partisipatoris - Ini adalah rahmat Roh Kudus yang diberikan kepada semua orang beriman di dalam Gereja. Roh Kuduslah yang mengenali dan menggerakkan Gereja sehingga dapat menjalankan tugas perutusannya yakitu mewartakan Sabda. Oleh Rm. Utomo, hal ini disebut 'asas kemuridan'.

- Gereja yang memberi kesaksian - Kebangkitan Kristus yang diwartakan Gereja diwujudkan dalam dialog kehidupan dengan semua orang (yang berlainan kepercayaan) menuju pembebasan yang integral. Dalam konteks KAS, dimunculkan istilah 'Gereja yang memasyarakat' sejak Ardas periode pertama.

- Agen transformasi - Dengan iman dan harapan yang berdimensi eskatologis, sudah menjadi penghayatan umat beriman untuk memahami bahwa kehidupan bukan berhenti di dunia ini. Perjuangan dalam perubahan sosial masyarakat didorong oleh penghayatan iman yang berdimensi eskatologis. Dunia yang lebih baik selalu harus diwujudkan.

\section{PENUTUP}

Perjuangan Gereja kaum miskin bukanlah sekedar slogan semu. Perjuangan bersama dan untuk orang kecil menjadi sebuah pilihan yang mendasar bagi Gereja. Justru dalam perjuangan inilah Gereja harus membuat strategi supaya karyanya ini tidak menjadi sebuah gerakan yang timpang. Maksudnya, di satu sisi membela kaum miskin tetapi di lain pihak memusuhi orang kaya. Atau malah sebaliknya, slogannya adalah Gereja kaum miskin tetapi praksisnya malah sebaliknya. Maksud bekerja bersama dan untuk orang kecil adalah bahwa dalam semangat kemiskinan dalam diri orang kecil itulah Gereja selalu berhadapan dengan kekuatan yang menindas dan mendominasi dunia sampai dengan saat ini. Kekuatan yang menindas inilah yang harus dilawan, siapapun pelakunya (agen). Inilah kesaksian nyata akan kabar gembira yang dibawa Kristus dan harus dilaksanakan Gereja di dunia ini. Di sinilah partisipasi umat Allah dalam karya penyelamatan menjadi konkret, yakni dalam misi pemberdayaan atau pembebasan manusia dan mengadakan perubahan bagi dunia. Perjuangan bersama dan untuk kaum miskin merupakan penghayatan iman Gereja akan karya penyelamatan Allah dalam diri Yesus Kristus yang memanggul salib dan dibenarkan Allah dengan kebangkitan-Nya. Pembebasan kemanusiaan yang integral inilah yang menjadi misi Gereja, khususnya Gereja Asia, sampai dengan detik ini.

\section{Alis Windu Prasetyo}

Anggota Serikat Jesus, sedang menjalani tersiat di Filipina: yawpsj@gmail.com

\section{Dionius Bismoko Mahamboro}

Mahasiswa program doktorat teologi moral di Innsbruck, Austria: mahamboro@gmail.com

\section{CATATAN AKHIR}

I. Suharyo, "Makin Beriman, Makin Bersaudara, Makin Berbela Rasa Melalui Pangan Sehat”, Surat Gembala Hari Pangan Sedunia, Oktober 2013.

Message of Pope Francis for World Food Day to Mr José Graziano da Silva Director General of the FAO (lih. http://w2.vatican.va/content/francesco/en/messages/food/docume nts/papa-francesco_20131016_messaggio-giornataalimentazione.html, diakses tanggal 2 Februari 2014).

Thomas C. Fox, Pantecost in Asia. A New Way of Being Church, 58.

KOMPAS, Sabtu, 27 Oktober 2007, hlm. A.

Lih. M. Amaladoss, Teologi Pembebasan Asia, 85-87.

Dalam tulisannya yang diberi judul "Kembalikan Kedaulatan Kaum Tani demi Kedaulatan Negeri Ini” sangat kelihatan sekali bahwa Rm. Utomo mau memperjuangkan hal itu. Juga dalam sebuah paper dengan judul "Tonggak-tonggak Sejarah Keselamatan di Ganjuran Gondang Lipuro” untuk mengulas Ensiklik Rerum Novarum 1891 sampai Deklarasi Ganjuran 1990 dan kelanjutannya, Rm. Utomo sangat getol mendengungkan spirit pembaharuan bagi bumi ini. Tampak bahwa ia ingin membumikan pemikiran demi pemulihan bumi ini benar-benar dijalankan. Lih. G. Utomo, Kembalikan Kedaulatan Kaum Tani demi Kedaulatan Negeri Ini, SPTN-HPS, Yogyakarta, 1999. 
7 Tim KAS, Garis-garis Besar Sejarah Gereja Keuskupan Agung Semarang, Semarang, 1991, 59-60; K. Steenbrink, Catholics in Indonesia, 395-397.

8 F. Wahono, "Revolusi Hijau: Dari Perangkap Involusi ke Perangkap Globalisasi”, dalam I. Wibowo \& F. Wahono (eds.), Neo-Liberalisme, Cindelaras Pustaka Rakyat Cerdas, Yogyakarta, 2003, 227-259.

9 G. Utomo, Pr, Kembalikan Kedaulatan Kaum Tani demi Kedaulatan Negeri Ini, 18, 21.

10 G. Utomo, Pr, Kembalikan Kedaulatan Kaum Tani demi Kedaulatan Negeri Ini, 25.

11 G. Utomo, Pr, Kembalikan Kedaulatan Kaum Tani demi Kedaulatan Negeri Ini, 9-19.

12 I. Wibowo, "Global Civil Society: Kekuatan Global Melawan Dampak Globalisasi,” Basis, No. 01-02, Th. Ke-56, Jan-Feb 2006, 6-12.

13 Dalam tulisannya Kembalikan Kedaulatan Kaum Tani demi Kedaulatan Negeri Ini, Rm Utomo memberi penjelasan bahwa pemiskinan masyarakat desa sudah terjadi sejak prakolonialisme Belanda dan diperparah oleh kolonialisme Belanda sampai sekarang, 2-4.

14 Otonomi desa tersebut ditopang secara struktural oleh IGO (Inlandische Gemeente Ordinantee) tahun 1906, Staatsblad no. 83, UU No. 22 Th 1999 pasal 93-111 selanjutnya diperbaharui dengan UU No. 32 Th 2004 (lih. Pasal 209-216). G. Utomo, “Tonggak-tonggak Sejarah Keselamatan di Ganjuran, Gondang Lipuro", artikel lepas.

15 G. Utomo, Pr, Kembalikan Kedaulatan Kaum Tani demi Kedaulatan Negeri Ini, 15-16.

16 G. Utomo, Pr, Kembalikan Kedaulatan Kaum Tani demi Kedaulatan Negeri Ini, 19.

17 Julio X. Labayen, "Historical Background of the Office for Human Development and The BISAs”, FABC Papers No. 6 Th. 1977, 2-9; Thomas C. Fox, Pantecost in Asia, 58-66.

18 FABC Papers No. 60.

19 Tissa Balasuriya, "Strategies of Action for Justice", FABC Papers No. 6 Th. 1977, 24-25.

20 Anthony Rogers merangkum kembali point-point dalam Sidang FABC V di Bandung (1990) mengenai 'the new way of being Church in Asia' dalam paper persiapan Sidang FABC VI. A. Rogers, "Integral Human Development and Justice for Peace at The Service of Life in The Context of Asia”, FABC Papers No. $72 \mathrm{~m}, 16$.

21 Bidang-bidang penerapan dari visi Gereja Asia (triple-dialogue) dalam dimensi keterlibatan sosial meliputi: ekologi dan lingkungan hidup, buruh industri, advokasi hak-hak azasi manusia, pembangungan desa yang berkelanjutan, minoritas suku dan budaya, keprihatinan terhadap kaum perempuan, orang miskin kota, orang muda, dan anak-anak, buruh migran, petani dan nelayan, korban bencana alam dan kemiskinan pada umumnya, partisipasi dalam demokrasi dan hak suara dalam perubahan kebijakan.
,"Mereka Dibodohkan Menjadi Petani Paket”, KOMPAS, Sabtu, 27 Oktober 2007.

Amaladoss, M., 2000. Teologi Pembebasan Asia (diterjemahkan dari Life in Freedom: Liberation Theologies from Asia), Yogyakarta: Pustaka Pelajar.

Balasuriya, T., 1997. "Strategies of Action for Justice”, FABC Papers No. 6, 24-25.

Fox, Thomas C., 2003. Pantecost in Asia. A New Way of Being Church, Quezon City: Claretian Publications.

Labayen, Julio X., 1977. "Historical Background of the Office for Human Development and The BISAs”, FABC Papers No. 6.

Labayen, Julio X., 1995. Revolution and the Church of the Poor, Quezon City: Claretian Publications.

Rogers, A., "Integral Human Development and Justice for Peace at The Service of Life in The Context of Asia”, FABC Papers No. 72m.

Steenbrink, K., 2007. Catholics in Indonesia 19031942. A Documented History. KITLV Press, Leiden.

Theological Advisory Commission of the FABC, 1991. “Theses on The Local Church", FABC Papers No. 60.

Tim KAS, 1991. Garis-garis Besar Sejarah Gereja Keuskupan Agung Semarang, Semarang.

Utomo, G., “Tonggak-tonggak Sejarah Keselamatan di Ganjuran, Gondang Lipuro”, artikel lepas.

Utomo, G., 1999. Kembalikan Kedaulatan Kaum Tani demi Kedaulatan Negeri Ini, Yogyakarta: SPTN-HPS.

Wahono, F., 2003. "Revolusi Hijau: Dari Perangkap Involusi ke Perangkap Globalisasi”, dalam I. Wibowo \& F. Wahono (eds.), NeoLiberalisme, Yogyakarta: Cindelaras Pustaka Rakyat Cerdas.

Wibowo, I., 2006. “Global Civil Society: Kekuatan Global Melawan Dampak Globalisasi,” Basis, No. 01-02, Th. Ke-56. 